\title{
Removal of Herbicide Glyphosate in a Drinking Water Treatment System
}

\author{
Angsuputiphant Navee and Jang-Eok Kim* \\ School of Applied Biosciences, College of Agriculture and Life Sciences, Kyungpook National University, \\ 1370 Sankyuk-dong, Buk-gu, Daegu 702-701, Korea
}

(Received March 12, 2009, Accepted March 26, 2009)

\begin{abstract}
The removal efficiency of herbicide glyphosate in a drinking water treatment system was investigated. Four major processes of a drinking water treatment system were selected and experiments were performed separately including; treatments by sodium hypochlorite ( $\mathrm{NaOCl}$ ), a sedimentation process by PAC (polyaluminum chloride), ozonation and a GAC (granular activated carbon) treatment. In the sodium hypochlorite experiment, about $50 \%$ of the glyphosate was removed by $2 \mathrm{mg} / \mathrm{L}$ of hypochlorite and more than $90 \%$ was eliminated when $5 \mathrm{mg} / \mathrm{L}$ of $\mathrm{NaOCl}$ was applied. Also, AMPA, the main metabolite of glyphosate, was treated with hypochlorite. More than $30 \%$ of the AMPA was removed by $2 \mathrm{mg} / \mathrm{L}$ of hypochlorite and $50 \%$ by $5 \mathrm{mg} / \mathrm{L}$. In the PAC experiment, it was determined that more than $60 \%$ could be removed. Further experiments were performed and the results indicated that the removed amount was dependent upon the amount of soil and upon the properties of the soil especially that of clay minerals. Ozonation could oxidize glyphosate to its byproducts at about a level of $50 \%$. In contrast, when $1 \mathrm{mg} / \mathrm{L} \mathrm{of}$ glyphosate was treated with GAC, the amount removed was negligible. The results of this experiment were conclusive. We confirmed that drinking water, which has been contaminated with water polluted with glyphosate can be effectively purified by the application of the drinking water treatment processes currently used
\end{abstract}

Key Words: Glyphosate, Removal efficiency, Sodium hypochlorite, PAC, Ozonation, GAC

\section{Introduction}

Glyphosate, $N$-(phosphonomethyl) glycine, is a widely popular herbicide known for its extensive non-selective spectrum, and rapid deactivation in soil ${ }^{1)}$. Glyphosate, which is the active ingredient in the trade names Roundup ${ }^{\circledR}$ and Rodeo ${ }^{\circledR}$ produced by Monsanto, is often used in various applications for broadleaf weeds and grasses ${ }^{2}$.

Glyphosate is one of the most widely used pesticides by volume. Usage in 1990 was estimated to be $11,595,000$ pounds ${ }^{3)}$. Due to the frequency of its usage, its effects on humans and other living organisms have been investigated. Glyphosate and its

\section{*연락저자:}

Tel: +82-53-950-5720 Fax: +82-53-953-7233

E-mail: jekim@knu.ac.kr technical formulation Roundup ${ }^{\circledR}$ (Active ingredient isopropylamine salt of glyphosate) have been found to be genotoxic. Damage to the DNA in kidney and liver tissue and in chromosomes has been reported in mice $^{4)}$. According to reports on human exposure to glyphosate there have not been any acute effects when the doses were small and of short duration. The maximum contaminants level (MCL) allowed in drinking water is $0.7 \mathrm{mg} / \mathrm{L}$ in the United State ${ }^{2,3)}$.

Glyphosate is believed to be strongly adsorbed by soil. Therefore, after applying glyphosate to soil including forests and field, it is believed that the probability of glyphosate leaching is low. Due to its high solubility in water (about $12 \mathrm{~g} / \mathrm{L}$ ), however, reports indicate that glyphosate has the potential for leaching to groundwater and to surface run-off water $^{1,2,5)}$. Moreover, its application has not been 
limited to soil, glyphosate has been used in aquatic ecosystems for weed control in some countries including the United State ${ }^{3)}$.

Since almost all drinking water consumed in the US and many other countries comes from a surface water system and because it is possible that glyphosate can be found in surface water, testing the removal efficiency of glyphosate by the available drinking water treatment processes is an essential and valuable water purification factor to study. The objective of this paper was to assess the removal efficiency of glyphosate in each processes of the present drinking water treatment system including; sodium hypochlorite treatment, coagulation by polyaluminum chloride, ozonation and adsorption by granular activated carbon.

\section{MATERIALS AND METHODS}

\section{Chemicals}

Glyphosate, analytical grade, and its main metabolite in soil, AMPA (aminophosphonic acid), were obtained from Monsanto, USA. Sodium hypochlorite $(12 \% \mathrm{NaClO})$ was purchased from Yakuri Pure Chemicals (Kyoto, Japan). Polyaluminum chloride solution $\left(13 \% \mathrm{Al}_{2} \mathrm{O}_{3}\right)$ was procured from the Daegu Water Treatment Institute (Korea). Two kinds of soil used in the coagulation experiment were collected from the Bokhyun and Ansim areas (Daegu, Korea), respectively. A laboratory research ozone generator (Ho-Dong Electric Company, Korea) was used. GAC (granular activated carbon) was purchased from Pica Corp., Japan.

\section{Treatment by sodium hypochlorite}

Five hundred $\mathrm{mL}$ of $1 \mathrm{mg} / \mathrm{L}$ of glyphosate and AMPA solution were prepared (the concentration of glyphosate used in all experiments was higher than MCL). The hypochlorite stock solution was added to beakers and altered to obtain the following hypochlorite concentration levels, $0.5,2$ and $5 \mathrm{mg} / \mathrm{L}$, respectively. The mixing speed was fixed at $100 \mathrm{rpm}$. The solutions were sampled at $30 \mathrm{~min}, 1 \mathrm{~h}, 2 \mathrm{~h}$ and $4 \mathrm{~h}$. Twenty-five $\mathrm{mL}$ of $1 \mathrm{mg} / \mathrm{L}$ glyphosate was prepared in a $40 \mathrm{~mL}$ vial with HPLC-grade water as the solvent, buffer solutions of $\mathrm{pH} 5, \mathrm{pH} 7$ and $\mathrm{pH}$ 9, respectively, were created. The hypochlorite stock solution was prepared and added to each vial to make $0.5 \mathrm{mg} / \mathrm{L}$ concentrations. The vials were capped, put in a $25^{\circ} \mathrm{C}$ water bath and shaken at the rate of $75 \mathrm{rpm}$. After $2 \mathrm{~h}$, the samples were transferred for analysis.

\section{Treatment by PAC}

Two kinds of soil colloid were prepared as follows: $10 \mathrm{~g}$ of each soil and $1 \mathrm{~L}$ of water were mixed together by a mixer. Then, supernatant and soil colloid was obtained by filtering the two soil suspensions individually through a $250 \mu \mathrm{m}$ sieve. The total suspended solid (TSS) of soil suspensions was determined at a temperature of about $105^{\circ} \mathrm{C}^{7)}$. In order to simulate a real system, $10 \%$ and $50 \%$ of the prepared soil colloid, which consists of both soil types, were mixed with a glyphosate solution to make an overall volume of $500 \mathrm{~mL}$. The soil suspension was mixed by a propeller at $120 \mathrm{rpm}$ for 5 minute, after that PAC was added to the system. After the addition of PAC, the propeller speed was increased to $200 \mathrm{rpm}$ for $1 \mathrm{~min}$ to increase the coagulation rate. Then, the speed was decreased to 50 rpm for an additional $10 \mathrm{~min}$. The suspension was sampled and the amount of glyphosate was analyzed in the supernatant after $30 \mathrm{~min}$ of settling time.

\section{Adsorption by clay minerals}

Forty $\mathrm{mg}$ of kaolinite and $40 \mathrm{mg}$ of montmorillonite, were weighed and prepared separately in 40 $\mathrm{mL}$ vials. Then $25 \mathrm{ml}$ of glyphosate solution was added. The concentration levels of glyphosate used in this experiment were $0.5,1,5,10$, and $20 \mathrm{mg} / \mathrm{L}$. The vials were capped, kept in a water bath at $25^{\circ} \mathrm{C}$ and shaken at $80 \mathrm{rpm}$. After $8 \mathrm{~h}$, the samples were centrifuged at $15,000 \mathrm{rpm}$ for $15 \mathrm{~min}^{8)}$. Then, the supernatants were taken for analysis.

The adsorption experiment data was examined by using the Freundlich or Langmuir equations. Those equations can be described as follows;

$$
\begin{array}{ll}
\mathrm{X}=\mathrm{KC}_{\mathrm{eq}}{ }^{1 / \mathrm{n}} & \text { Freundlich equation } \\
\mathrm{X}=\mathrm{X}_{\mathrm{m}} \mathrm{KC}_{\mathrm{eq}} /\left(1+\mathrm{KC}_{\mathrm{eq}}\right) & \text { Langmuir equation }
\end{array}
$$

Where $X$ is the amount of pesticide adsorbed per unit weight of the soil $(\mathrm{mg} / \mathrm{kg}), X_{m}$ is the maximum 
amount of pesticide adsorbed $(\mathrm{mg} / \mathrm{kg}), \mathrm{C}_{\mathrm{eq}}$ is the equilibrium concentration of the pesticides $(\mathrm{mg} / \mathrm{L}), \mathrm{K}$ is an affinity parameter, and $1 / \mathrm{n}$ is an empirical parameter.

\section{Ozonation}

Ozone was bubbled into $4,000 \mathrm{~mL}$ of $1 \mathrm{mg} / \mathrm{L}$ of glyphosate at the ambient temperature. The samples were collected at 5, 15, 30, 60, 120, and $240 \mathrm{~min}$, and then analyzed the concentration of glyphosate. The ozone was analyzed on the basis of a ozone demand semi-batch method ${ }^{7}$.

\section{Removal by GAC treatment}

Five-hundred $\mathrm{mL}$ of a $1 \mathrm{mg} / \mathrm{L}$ glyphosate solution was prepared and added to a beaker. GAC was weighed, added to beakers and mixed by a jar-test machine (Shin Seang Instrument Co., Korea). The weight percentages of GAC were $0.5 \%(\mathrm{w} / \mathrm{v})$ and $1 \%$ $(\mathrm{w} / \mathrm{v})$, respectively. The propeller speed was fixed at $100 \mathrm{rpm}$ in this experiment. The supernatant was sampled at $5 \mathrm{~min}, 15 \mathrm{~min}, 30 \mathrm{~min}, 1 \mathrm{~h}$ and $2 \mathrm{~h}$, respectively to determine the remaining glyphosate.

\section{Analytical procedure}

Before being analyzed by high performance liquid chromatography (HPLC) with a fluorescence detector, the supernatants of glyphosate and AMPA were derivatized with 9-fluorenylmethylchloroformate to yield the highly fluorescent derivatives of the analytes, which were sensitive to a fluorescence detector $^{9,10)}$. The analytical procedure was as follows: First, $1 \mathrm{~mL}$ of each sample was added to a test tube containing $2 \mathrm{~mL}$ of $0.075 \mathrm{M}$ sodium tetraborate $\left(\mathrm{Na}_{2} \mathrm{~B}_{4} \mathrm{O}_{7}\right)$ to adjust the $\mathrm{pH}$. Then, $3 \mathrm{~mL}$ of $0.015 \mathrm{M}$ 9-fluorenylmethyl chloroformate was added for a derivatization reaction. After shaking and standing for $30 \mathrm{~min}, 5 \mathrm{~mL}$ of pure dichloromethane was added for partition. The water layer $(2 \mathrm{~mL})$ was collected and analyzed by HPLC using a fluorescence detector. A Shimazu-10A high performance liquid chromatography system (Shimazu Co., Kyoto, Japan) was equipped with a fluorescence detector (Gmbh, Eresing, Germany). A fluorescence detector was used at the excitation and emission wavelengths of $265 \mathrm{~nm}$ and $315 \mathrm{~nm}$, respectively. A $250 \mathrm{~mm} \times 4 \mathrm{~mm}$ column $\left(\mathrm{NH}_{2} 5 \mu \mathrm{m}\right.$, Merck, Germany) was used. The mobile phase was composed of acetonitrile and $0.1 \mathrm{M}$ of $\mathrm{KH}_{2} \mathrm{PO}_{4}$ (5: 5 for analysis of glyphosate and $3: 7$ for analysis of AMPA).

\section{RESULTS AND DISCUSSION}

About $50 \%$ of the glyphosate was removed with a $2 \mathrm{mg} / \mathrm{L}$ hypochlorite treatment and more than $90 \%$ was eliminated when $5 \mathrm{mg} / \mathrm{L}$ of hypochlorite was applied as shown in Fig. 1. When AMPA, the main metabolite of glyphosate was treated with hypochlorite more than $30 \%$ of the AMPA was removed with a $2 \mathrm{mg} / \mathrm{L}$ hypochlorite treatment and $50 \%$ at $5 \mathrm{mg} / \mathrm{L}$ as shown in Fig. 2.

It is well known that hypochlorite can react readily with nitrogenated compounds ${ }^{11)}$. The reaction between the nitrogenated compounds and sodium hypochlorite was found to follow an overall second order rate law, the first order was relative to the

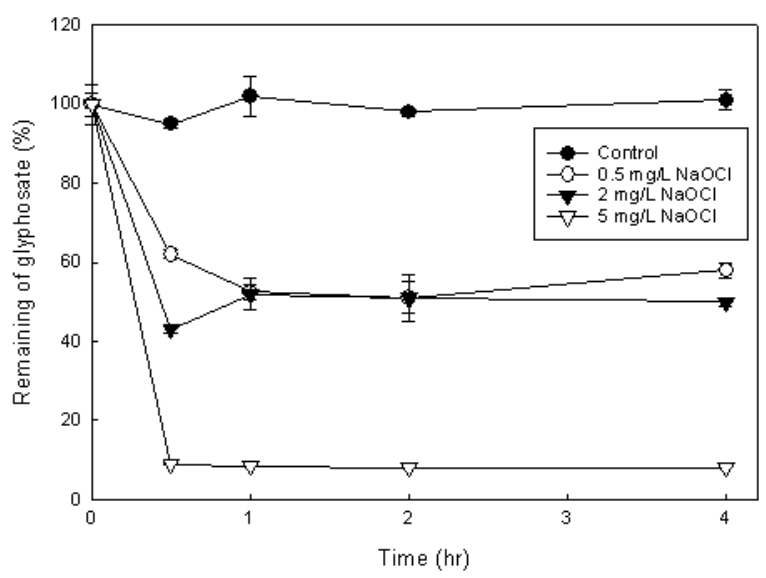

Fig. 1. Removal efficiency of glyphosate by $\mathrm{NaOCl}$.

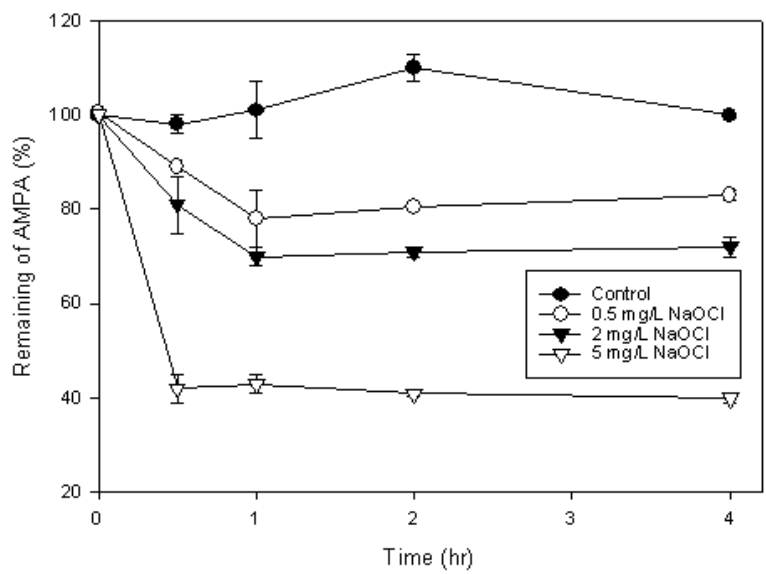

Fig. 2. Removal efficiency of AMPA by $\mathrm{NaOCl}$. 
amine and the first order was relative to the sodium hypochlorite:

$$
\mathrm{R}=\mathrm{k}[\mathrm{NaOCl}][\text { amine }]
$$

The rate constants of reactions between sodium hypochlorite and many nitrogenated compounds have been calculated before by researchers. Glycine, the basic compound of glyphosate, was found to react with hypochlorite effectively exhibiting a high rate constant $\mathrm{k}$ of about $11.3 \times 10^{7} \mathrm{~mol}^{-1} \mathrm{dm}^{-3} \mathrm{~s}^{-1}{ }^{11}$.

AMPA, which is the main metabolite of glyphosate in soil, was not found to be a byproduct of the reaction between glyphosate and hypochlorite.

Generally, products between nitrogenous compounds and sodium hypochlorite are chloramines. Chlorine can substitute the $\mathrm{H}$ atom in an amine group to form monochloramine. The substitution of chlorine can continue to form dichloramine and trichoramine if there are more hydrogen atoms attached to the amine group. Initial chlorine-to-nitrogen $(\mathrm{Cl}: \mathrm{N})$ ratio, $\mathrm{pH}$, temperature, and contact time are all important factors in determining which kinds of chloramines will be predominant ${ }^{12)}$. The reactions between organic amino compounds and hypochlorite should in theory be the same as the reactions between ammonia and hypochlorite ${ }^{11,13,14)}$. Therefore, the production of glyphosate and AMPA, when resulting from a reaction with hypochlorite, might be chloramine compounds. It is monochloramine in the case of glyphosate and mono and dichloramine in the case of AMPA.

When the results were considered, it was clear that AMPA was more difficult to oxidize with $\mathrm{NaOCl}$ than glyphosate. The reason may have been the disappearance of the carboxylic group in AMPA. In a glyphosate structure, both the phosphonic and carboxylic groups are electrophilic groups and try to attract non-paired electrons of nitrogen atoms to them. Since the electronegativity of both groups do not differ a great deal, the net of the dipole moment around the nitrogen atom is small. As a result, $\mathrm{NaOCl}$ can oxidize the $\mathrm{N}$ atom easily. On the other hand in AMPA, the disappearance of the carboxylic group results in the higher dipole moment. The non-paired electrons of nitrogen are attracted pretty strongly by the phosphonic group resulting in the inhibition of the oxidation of the $\mathrm{N}$ atom by $\mathrm{NaOCl}$.
The glyphosate removal experiments, that tested the effects of various $\mathrm{pH}$ were performed because the $\mathrm{pH}$ level of the inlet water, normally, is not adjusted during sodium hypochlorite treatment $(\mathrm{pH}$ is controlled before the sedimentation process which follows the hypochlorite treatment). From the results, it was apparent that the $\mathrm{pH}$ level can affect the reaction between glyphosate and $\mathrm{NaClO}$. When the $\mathrm{pH}$ is increased, the removal efficiency of glyphosate by $\mathrm{NaClO}$ also increased. A pH level of 9 was more effective than that of 7 and 5 . The results were similar to that of other research in that the rate of reaction between the nitrogenous compounds and hypochlorite was $\mathrm{pH}$ dependent. Abia et $\mathrm{al}^{11)}$ determined the relationship between $\mathrm{K}$ (rate constant) and $\mathrm{pH}$ as follows :

$$
\mathrm{K}=\frac{\mathrm{a}\left[\mathrm{H}^{+}\right]}{\left(\mathrm{b}+\left[\mathrm{H}^{+}\right]\right)\left(\mathrm{c}+\left[\mathrm{H}^{+}\right]\right)}
$$

where, a, b, and c are constants to be optimized.

At the lower $\mathrm{pH}$ level, $\mathrm{HOCl}$ can react with $\mathrm{H}^{+}$ and form $\mathrm{H}_{2} \mathrm{O}$ and $\mathrm{Cl}_{2}$. As a result, when the amount of oxidizing agent $(\mathrm{NaOCl})$ was decreased, the removal efficiency of glyphosate decreased.

In the coagulation process, it was apparent that glyphosate can be removed by adsorption. When there was no addition of the coagulant, PAC, the adsorbed amount of glyphosate increased when the TSS (total suspended solid) in the soil suspension increased both in soil 1 and soil 2 (Fig. 3, 4). After the evaluation of the TSS and the soil properties of both soils (Table 1), even though the TSS and the amount of organic matter in soil 2 used in the experiment were greater than those of soil 1, it seemed that soil 1 could adsorb glyphosate more effectively than soil 2 . Therefore, the amounts of clay minerals in soil 1 were determined to be the main factor, which caused greater adsorption. These results parallel those of existing research ${ }^{15-18)}$, which has determined that the binding of glyphosate to soil was attributed to the reaction between the phosphonic group and the polyvalent cations adsorbed on clay.

With the addition of $50 \mathrm{mg} / \mathrm{L}$ of PAC, the removal efficiency of glyphosate increased to about $20-40 \%$. PAC is generally used to decrease the zeta 


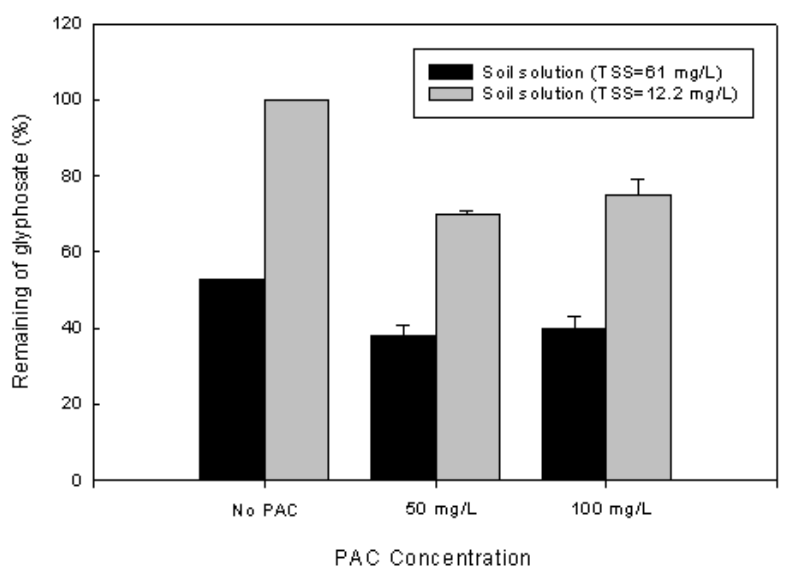

Fig. 3. Removal efficiency of glyphosate by PAC in soil 1.

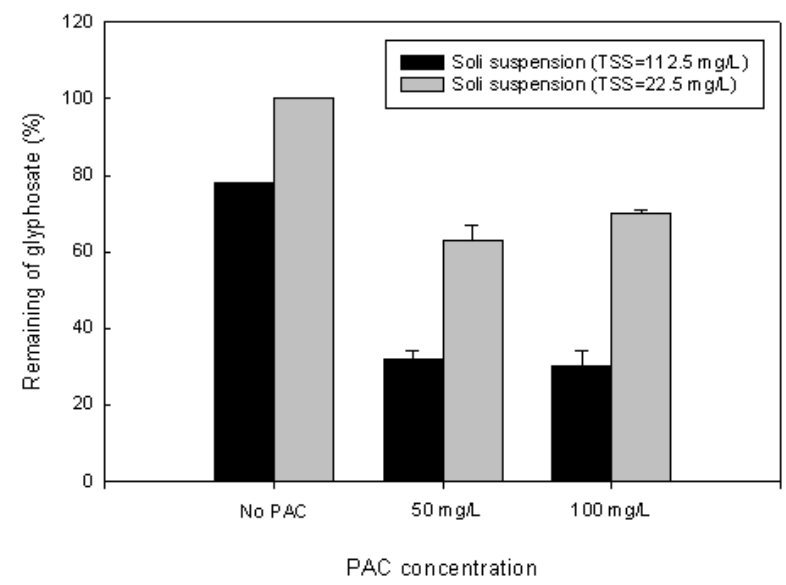

Fig. 4. Removal efficiency of glyphosate by PAC in soil 2.

Table 1. Physico-chemical properties of soils used in PAC treatment

\begin{tabular}{|c|c|c|c|c|c|c|c|}
\hline \multirow{2}{*}{ Soil } & \multirow{2}{*}{ Texture(a) } & \multicolumn{3}{|c|}{ Particle size dist. (\%) } & \multirow{2}{*}{$\begin{array}{c}\mathrm{pH} \\
1: 5(\mathrm{~b})\end{array}$} & \multirow[t]{2}{*}{ O.M.(\%) } & \multirow{2}{*}{$\begin{array}{c}\text { CEC } \\
(\mathrm{cmol} / \mathrm{kg})\end{array}$} \\
\hline & & Clay & Silt & Sand & & & \\
\hline Soil 1 & $\mathrm{LiC}$ & 33.0 & 42.0 & 25.0 & 7.3 & 1.0 & 13.2 \\
\hline Soil 2 & $\mathrm{SiCL}$ & 16.0 & 70.6 & 13.4 & 7.4 & 3.8 & 13.9 \\
\hline
\end{tabular}

a) LiC : light clay, SiCL : silty clay loam b) Soil : Deionized water

potential on the surface of colloids, thus enducing rapid sedimentation. The availability of aluminum ions in PAC is the predominant factor responsible sinking suspended colloids. When aluminum ions enter the water, the aluminum ions become hydrated, meaning that the water molecules attach themselves to the aluminum ions. Also, anions present in water can attach themselves to these alumimum ions. These reactions result in large, positively charged molecules that have aluminum ions at their center. These particles may have charges as high as +4 . Since glyphosate has functional carboxyl and phosphate groups which are negatively charged, it can react with aluminum ions easily. However, when the concentration of PAC, increased from 50 to 100 $\mathrm{mg} / \mathrm{L}$, the removal efficiency did not increase in both kinds of soil. This result may have been due to the amount of clay present. Aluminum ions attached to the functional groups of glyphosate need a greater amount of colloids in order to attach and settle down.

It appeared that the addition of PAC could increase the removal efficiency in the system containing soil 2 more than in a system that has soil 1. Following the addition of $100 \mathrm{ppm}$ of PAC, soil 2 could adsorb about $70 \%$ of the glyphosate and about $62 \%$ in soil 1 . This could have been due to the higher amount of organic matter in soil 2. Without the addition of PAC, more glyphosate was adsorbed in soil 1 because it had more clay minerals. However, when an excessive amount of PAC, which also had polyvalent cations similar to those found in clay minerals, was added the clay mineral content of the soil was not estimated to be a major factor. Humic substances were then determined to have been the major factor for the adsorption. The adsorption of glyphosate was found to be directly proportional to the humic content of the soil. The greater the humic content the greater the degree of adsorption. Related studies concluded that glyphosate was found to be more easily and reactively adsorbed by humic substances, even more so than clay minerals. Adsorption between humic substances and glyphosate has been explained as multiple hydrogen bondings which can occur among the various acidic and oxygen-containing groups of both molecules ${ }^{19)}$.

The results in Table 2 indicate that not only the amount of clay minerals present but also the kinds of clay can affect the adsorption of glyphosate.

Montmorillonite, which has a higher specific 
Table 2. Freundlich and Langmuir constants for the adsorption of glyphosate on kaolinite and montmorillonite

\begin{tabular}{ccccccc}
\hline & \multicolumn{3}{c}{ Freundlich equation } & \multicolumn{4}{c}{ Langmuir equation } \\
\cline { 2 - 7 } Clay & $\mathrm{K}$ & $1 / \mathrm{n}$ & $\mathrm{r}$ & $\mathrm{X}_{\mathrm{m}}$ & $\mathrm{K}$ & $\mathrm{r}$ \\
\hline Kaolinite & 712 & 0.5353 & 0.95 & 1132.95 & 2.28 & 0.90 \\
Montmorillonite & 1085.42 & 0.5521 & 0.96 & 4155 & 0.6825 & 0.99 \\
\hline
\end{tabular}

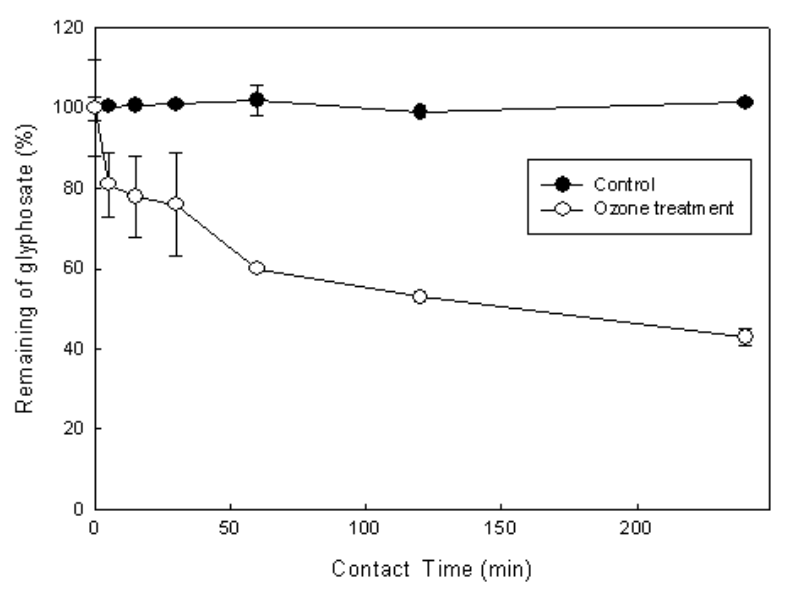

Fig. 5. Removal efficiency of glyphosate by ozonation.

surface area (about $700-800 \mathrm{~m}^{2} / \mathrm{g}$ ) and higher cation exchange capacity (about 70-100 cmol/ kg), has shown a very high adsorption property compared to kaolinite (specific surface area about $7-30 \mathrm{~m}^{2} / \mathrm{g}$, CEC about $1-10 \mathrm{cmol} / \mathrm{kg})^{20)}$. A higher $\mathrm{K}$ (in Freundlich isotherm) and higher $\mathrm{Xm}$ (in Langmuir isotherm) could be observed when glyphosate was adsorbed by the montmorillonite.

About $50 \%$ of the glyphosate was removed by ozonation after $4 \mathrm{hr}$ as shown in

Fig.5. The ozone dose used in this experiment (375 $\mathrm{mg} / \mathrm{min}$ ) was much greater than solubility of ozone in water, which has been generally estimated to be less than $40 \mathrm{mg} / \mathrm{L}$. The rate limiting step of the reaction was found to be the dissolving of ozone into water. The solubility of ozone in water has been found to obey Henry's Law and is a function of the temperature and the $\mathrm{pH}$ level.

The ozone can decompose into $\mathrm{OH}$. (hydroxyl radicals) which are the strongest oxidants in water ${ }^{21)}$. Ozone is a very selective oxidant, whereas $\mathrm{OH}$ radicals are not selective and react quickly with many dissolved compounds. Under the conditions of this experiment, however, where the $\mathrm{pH}$ was not high nor was there the addition of hydrogen peroxide, the amount of $\mathrm{OH}$ radicals should have been less.
Therefore, it may be concluded that glyphosate was oxidized predominantly by ozone.

Even though the products were not investigated in this experiment, research was performed to identify the products of some amino compounds including glycine, the basic component of glyphosate and AMPA ${ }^{22}$. In those experiments after excessive ozonation, glycine decomposed into ammonium ions as the major inorganic nitrogen species (about 60\%) and also nitrite (20\%) and nitrate ions (20\%). Also, organic products were found which included oxalic and oxamic acid. These products are not known to be harmful to human health. Currently, the only form of ozonation regulated in drinking water treatment is bromate, which is formed during the ozonation of water containing bromide ${ }^{23)}$. Hence, the by-products of glyphosate formed during ozonation may be less harmful than those of glycine.

Futhermore, a batch experiment was also performed (spiking the glyphosate in the saturated ozone) but because the half-life of ozone in water is very short (ranging from a minute to $1 \mathrm{~h}$ depending on water characteristics), the removal efficiency was found to be low (about 10\%, data not shown) ${ }^{24)}$.

Even though the results from this experiment did not provide much definitive information, at least it confirmed that more glyphosate will be removed $(>50 \%)$ in a real drinking water treatment system in which ozone solubility can be increased to a greater degree than it was than in this experiment. This can be achieved by simple methods, for example pressurizing ozone gas, decreasing the temperature, increasing the flow rate of ozone gas, etcetera.

The removal efficiency of glyphosate by GAC was the least effective among water treatment process as shown in Fig. 6. Actually, it was not surprising that glyphosate, a polar compound, was not readily adsorbed by GAC which is commonly used to adsorb non-polar compounds. A portion of the glyphosate adsorption by GAC may have resulted from weak physical adsorption. This is visibly evident in the 


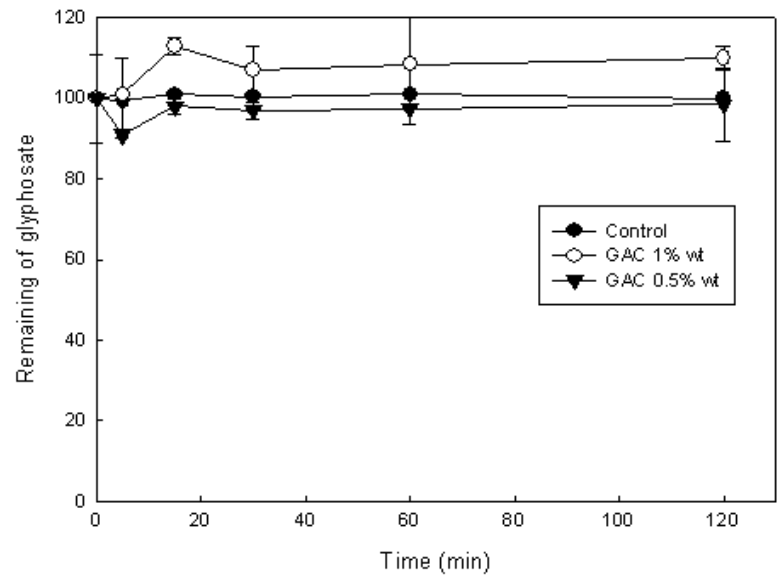

Fig. 6. Removal efficiency of glyphosate by GAC.

graph lines rising up and falling down over the duration of the experiment.

\section{CONCLUSIONS}

The sodium hypochlorite treatment was very effective with respect to the removal of glyphosate. In the coagulation process, the amount and kinds of clay minerals were determined to be important factors accountable for the removal of glyphosate. It was also determined that ozone could transform glyphosate into other compounds but its low solubility in water limited the rate of reaction. The adsorbed amount of glyphosate, which is a polar compound, by GAC was found to be negligible. However, it can be reasoned that even though glyphosate can contaminate surface water and enter the drinking water processing system, it is apparent that glyphosate can be effectively removed from the drinking water treatment system.

\section{REFERENCES}

1. Shifu, C. and Yunzhang, L. (2007) Study on the photocatalytic degradation of glyphosate by $\mathrm{TiO} 2$ photocatalyst, Chemosphere. 67, 1010-1017.

2. Baylis, A. D. (2000) Why glyphosate is a global herbicide: strengths, weaknesses and prospects, Pest. Manage. Sci. 56, 299-308.

3. Woodburn, A. (2000) Glyphosate: production, pricing and use worldwide, Pest. Manage. Sci. 56, 309-312.
4. Bolognesi, C., Bonatti, S., Degan, P., Gallerani, E., Peluso, M., Rabboni, R., Roggieri, P. and Abbondandolo, A. (1997) Genotoxic activity of glyphosate and its technical formulation Roundup, J. Agric. Food Chem. 45, 1957-62.

5. Edwards, W. M., Triplett Jr, G. B. and Kramer, R. M. (1980) A watershed study of glyphosate transport in runoff, J. Environ. Qual. 4, 661-665.

6. Schweinsberg, F., Abke, W., Rieth, K., Rohmann, U. and Zullei-Seibert, N. (1999) Herbicide use on railway tracks for safety reasons in Germany. Toxicol. Let. 107, 201-205.

7. Greenberg, A. E., Clesceri, L. S. and Eaton, A. D. (1992) Standard Methods for the Examination of Water and Wastewater, $18^{\text {th }}$ Eds., American Public Health Association, Washington, USA, p. 2350-2540.

8. OECD. (1993) OECD guidelines for testing chemicals 1, 106, p.23.

9. Sancho, J. V., Hernandez, F., Lopez, F. J., Hogendoorn, E. A., Dijkman, E. and Zoonen, P. V. (1996) Rapid determination of glufosinate, glyphosate and aminomethylphosphonic acid in environmental water samples using precolumn fluorgenic labeling and coupled-column liquid chromatography. J. Chromatogr A, 737, 75-83.

10. Glass, R. L. (1983) Liquid chromatographic determination of glyphosate in fortified soil and water samples. J. Agric. Food Chem. 31, $280-82$.

11. Abia, L., Armesto, X. L., Canle, M. L., Garcia, M., V., and Santaballa, J. A. (1998) Oxidation of aliphatic amines by aqueous chlorine. Tetrahedron, 54, 521-30.

12. Donnermair, M. M. and Blatchley III, E. R. (2003) Disinfection efficacy of organic chloramines, Water Res. 37, 1557-70.

13. Armesto, X. L., Canle, M., and Santaballa, J. A. (1992) a-Amino acids chlorination in aqueous media, Tetrahedron, 49, 275-84.

14. Armesto, X. L., Canle, M., Garcia, M. V., Losada, M., and Santaball, J. A. (1994) N reactivity vs. O reactivity in aqueous chlorination, Int. J. Chem. Kinet. 26, 1135-41.

15. Morillo, E., Undabeytia, J., Maqueda, C. and Ramos, A. (2000) Glyphosate adsorption on soils of different characteristics. Influence of copper addition, Chemosphere. 40, 103-107.

16. Gimsing, A. L. and Borggaard, O. K. (2002) Effect 
of phosphate on the adsorption of glyphosate on soils, clay minerals and oxides. Int. J. Environ. Anal. Chem. 82, 545-552.

17. Sheals, J., Sjöberg, S. and Persson, P. (2002) Adsorption of glyphosate on goethite: molecular charcterization of surface complexes. Environ. Sci. Tech. 36, 3090-3095.

18. Barja, B. C. and Alfonso, M. D. (2005) Aminomethylphosphonic acid and glyphosate adsorption onto goethite: a comparative study. Environ. Sci. Technol. 39, 585-592.

19. Piccolo A., Celano, G. and Conte, P. (1996) Adsorption of glyphosate by humic substances, J. Agric. Food Chem. 44, 42-46.

20. McBride, M. B. (1994) Environmental Chemistry of
Soils, Oxford University Press, New York, USA, p.356-372.

21. Staehelin, J., and Hoigne, J. (1985) Decomposition of ozone in water in the presence of organic solutes acting as promoters and inhibitors of radical chain reactions, Environ. Sci. Technol. 19, 1206-13.

22. Berger, P., Karpel Vel Leitner, N., Dore, M., and Legube, B. (1999) Ozone and hydroxyl radicals induced oxidation of glycine, Water Res. 33, 433-41.

23. Gottschalk, C., Libra, J. A. and Saupe, A. (2000) Ozonation of Water and Waste Water, WILEY-VCH, Weinheim, Federal Republic of Germany, p.21-36.

24. Speth, T. F. (1993) Glyphosate removal from drinking water, J. Environ. Engine. 119, 1139-1157. 